\title{
Antibodies to citrullinated peptides in tuberculosis
}

\author{
I. Lima • R. C. Oliveira • A. Atta • S. Marchi • \\ L. Barbosa $\cdot$ E. Reis $\cdot$ M. G. Reis $・$ M. B. Santiago
}

Received: 21 June 2012 / Revised: 13 December 2012 / Accepted: 11 January 2013 /Published online: 24 January 2013

(C) Clinical Rheumatology 2013

\begin{abstract}
Rheumatoid arthritis (RA) is an autoimmune disease characterized by symmetric polyarthritis, rheumatoid factor (RF) positivity, and bone erosions. Recently, research has been conducted on anti-citrullinated peptide antibodies (ACPAs) to which there are greater sensitivity and specificity than RF. However, these antibodies have also been described in infectious diseases, particularly tuberculosis (TB), placing the high specificity of the test in doubt. The aim of this research was to study the prevalence of ACPAs in TB, RA, and healthy controls. Patients with bacteriologically confirmed pulmonary tuberculosis, RA (ACR criteria), in addition to healthy controls were included. ACPAs were researched by: anti-cyclic citrullinated peptide (CCP), anti-modified citrullinated vimentin (MCV), and RF by ELISA. The study was conducted in 50 TB patients, 50 with RA, and 20 controls. Anti-CCP antibodies were found in 39 (78 \%) of the RA patients (median titer, $128 \mathrm{U}$ ), whereas antiMCV antibodies were found in $25(50 \%)$. Of the patients with TB, two (4\%) had positivity for anti$\mathrm{CCP}$ and anti-MCV and no patient in the control group tested positive for these antibodies. Sensitivity of anti-
\end{abstract}

\footnotetext{
I. Lima $\cdot$ M. B. Santiago

Escola Bahiana de Medicina e Saúde Pública, Salvador, Bahia, Brazil

R. C. Oliveira $\cdot$ A. Atta

Faculdade de Farmácia da Universidade Federal da Bahia, Salvador, Brazil

S. Marchi $\cdot$ L. Barbosa $\cdot$ E. Reis $\cdot$ M. G. Reis

Fundação Oswaldo Cruz, Salvador, Brazil

M. B. Santiago $(\bowtie)$

Serviços Especializados em Reumatologia da Bahia, Rua Conde Filho 117, Graça,

Salvador, Bahia CEP 40.150-150, Brazil

e-mail: mitter@svn.com.br
}

CCP for RA was $78 \%$ (confidence interval (CI), 63 to $88 \%$ ) and specificity was $97 \%$ (CI, 89 to $99 \%$ ) while the sensitivity of anti-MCV was $50 \%$ (CI, 35-64\%) and specificity was $97 \%$ (CI, 89 to $99 \%$ ). RF was positive in 40 samples $(80 \%)$ of RA, in $30(60 \%)$ of $\mathrm{TB}$, and in $1(5 \%)$ of the controls. Our findings showed high sensitivity of anti-CCP and high specificity of both anti-CCP and anti-MCV antibodies for RA, even in a population with high incidence of tuberculosis. The higher frequency of positivity of ACPA in TB observed in previous studies may be attributed to methodological factors.

Keywords ACPA $\cdot$ Anti-CCP $\cdot$ Anti-MCV $\cdot$ Rheumatoid arthritis $\cdot$ Rheumatoid factor $\cdot$ Tuberculosis

\section{Introduction}

Rheumatoid arthritis (RA) is an autoimmune disease that affects around $1 \%$ of the adult population [1]. In Brazil, its prevalence ranges from 0.2 to $1 \%[2,3]$. The diagnosis of RA is based on clinical, radiological, and laboratory criteria $[4,5]$. Advances in laboratory tests and in imagining exams made it possible to diagnosis RA at an earlier stage of the disease [6]. With respect to laboratory tests, research into antibodies against citrullinated peptides (ACPAs) has demonstrated their higher specificity and positive predictive value than rheumatoid factor (RF) [7-9]. On the other hand, recent studies have demonstrated the presence ACPAs by ELISA in several infectious diseases, particularly tuberculosis (TB) $[8$, 10-14]. The aim of this research was to study the prevalence of ACPAs in patients with TB, RA, and healthy controls, using two methods: anti-cyclic citrullinated peptides (CCP) and anti-modified citrullinated vimentin (MCV). 


\section{Material and methods}

\section{Patients}

This was a cross-sectional study including patients with RA (ACR criteria) [5], those with pulmonary TB (diagnosed on the basis of radiologic exam and confirmed by positive sputum test for acid-fast bacillus) before or within a month of treatment, and healthy controls (C) selected from among blood donors. All patients were over the age of 18 years, voluntarily agreed to participate in the study, and signed a term of free and informed consent. Patients with RA who had an associated infectious condition were excluded. The patients were submitted to clinical evaluation to obtain data about gender, age, time of diagnosis, smoking, comorbidities, medications in use, and osteoarticular symptoms. This study was approved by the research ethics committees of the institutions involved in the project.

\section{Laboratory tests}

All sera were tested for anti-CCP (INOVA), anti-MCV, and RF by ELISA (Orgentec) in accordance with the manufacturers' instructions. Values higher than $20 \mathrm{U}$ were considered positive for anti-CCP and anti-MCV and higher than $25 \mathrm{U}$ for RF.

\section{Statistical analysis}

Gender and positivity of ACPAs and RF were presented in frequencies; age, time of diagnosis, and time of use of antiTB therapy were presented in the form of mean \pm standard deviation or median plus interquartile interval (IQ). Comparison of the median of ACPA titers among the groups was made by the Kruskal-Wallis test. Correlation between antiCCP and anti-MCV in the RA population was evaluated by Spearman's test. Sensitivity and specificity of anti-CCP,
anti-MCV, and RF for RA were calculated by means of the program http://faculty.vassar.edu/lowry/clin1.html and the results were presented with a confidence interval (CI) of $95 \%$.

\section{Results}

The study was conducted in 50 TB patients (52\% women), mean age of $48 \pm 17$ years, and the positivity of anti-CCP was observed in only two (4\%) (86 and $105 \mathrm{U})$ - a result quite similar to anti-MCV (69 and $196 \mathrm{U})$. These patients also presented positivity of RF (352 and $224 \mathrm{U}$ ). Among the patients with TB, the RF was positive in 30 (60\%). Of the two patients positive for ACPA, one complained of pain in the knees and a diffuse pain in the left hand, associated with a trauma in the past. These two patients were reevaluated 1 year after initial evaluation and none presented manifestations compatible with RA. Fifty patients with RA were included (94\% women), mean age of $55 \pm 13$ years and median time of diagnosis of 13 years (IQ, 6 to 17). Thirty-nine (78\%) were positive for anti-CCP, with a median titer of $128 \mathrm{U}$ (IQ, 24 to $233) ; 25(50 \%)$ were positive for anti-MCV, median titer of $21 \mathrm{U}$ (IQ, 10-218), and 40 (80\%) were positive for RF median titer of $368 \mathrm{U}$ (IQ, 32-658). There was statistically significant difference between the mean titers of ACPAs and RF among three studied groups. The sensitivity of anti-CCP for diagnosis of RA was $78 \%$ (CI, 63 to $88 \%$ ) and specificity was $97 \%$ (CI, 89 to $99 \%$ ). Lower sensitivity was observed for anti-MCV (50\%; CI, 35 to $64 \%$ ), nevertheless maintaining high specificity of $97 \%$ (CI, 89 to $99 \%$ ) for RA. Statistically significant correlation was observed between the anti-CCP and anti-MCV titers (Spearman, $p>0.001$ and $r=0.6$ ) in the RA population. As regards RF, sensitivity was $80 \%$ (CI, 65 to $89 \%$ ) and specificity was $55 \%$ (CI, 43 to $67 \%$ ). The demographic and clinical data and results of tests in the three groups of patients are presented in Table 1
Table 1 Clinical, epidemiological, and laboratorial characteristics of the three groups of patients studied

$R A$ rheumatoid arthritis, $T B$ tuberculosis, RIP rifampicin/ isoniazid/pyrazinamide, $R F$ rheumatoid factor, $N A$ not applicable ${ }^{*} p<0.0001$

${ }^{\mathrm{a}}$ Mean \pm standard deviation

${ }^{\mathrm{b}}$ Median and interquartile interval

${ }^{\mathrm{c}}$ Diagnosis time in years

${ }^{\mathrm{d}}$ Diagnosis time in days

\begin{tabular}{|c|c|c|c|}
\hline & RA (50) & TB (50) & Controls (20) \\
\hline Female $(\%)$ & 94 & 52 & 40 \\
\hline Age (years) & $55( \pm 13)^{\mathrm{a}}$ & $48( \pm 17)^{\mathrm{a}}$ & $35(28-42)^{b}$ \\
\hline Smoking (\%) & 13 & 42 & 0 \\
\hline Time of diagnosis (years ${ }^{\mathrm{c}}$ or days ${ }^{\mathrm{d}}$ ) & $8(2-18)^{\mathrm{b}, \mathrm{c}}$ & $8(2-18)^{\mathrm{b}, \mathrm{d}}$ & NA \\
\hline Time of RIP therapy (days) & NA & $8(2-19)^{\mathrm{b}}$ & NA \\
\hline Positivity of anti-CCP (\%) & 78 & 4 & 0 \\
\hline Anti-CCP titer $(\%)$ & $128(24-233)^{\mathrm{b}, *}$ & $4(2-9)^{\mathrm{b}, *}$ & $2(1-2)^{\mathrm{b}, *}$ \\
\hline Positivity of anti-MCV (\%) & 50 & 4 & 0 \\
\hline Anti-MCV titer (units) & $21(10-218)^{\mathrm{b}, *}$ & $9(7-12)^{\mathrm{b}, *}$ & $2(2-3)^{\mathrm{b}, *}$ \\
\hline RF positivity (\%) & 80 & 60 & 5 \\
\hline RF titer (units) & $368(32-658)^{\mathrm{a}, *}$ & $30(19-43)^{\mathrm{a}, *}$ & $6(3-11)^{\mathrm{a}, *}$ \\
\hline
\end{tabular}




\section{Discussion}

ACPAs in RA have been investigated for a long time, and initially, this was done by means of anti-perinuclear factor detection [15]. Since then, search for various antibodies against citrullinated peptides has been developed, and in 2000, the first kit for anti-CCP was launched [8]. In a recent study that reviewed 151 articles, the sensitivity of anti-CCP ranged from 40 to $93 \%$ and specificity from 70 to $100 \%$ for the diagnosis of RA [9]. This finding is in accordance with our previous experience as we observed a sensitivity of $79 \%$ and a specificity of $93 \%$ for anti-CCP for the diagnosis of RA, using a population with systemic sclerosis and primary biliary cirrhosis as control [16].

On the other hand, recent studies have demonstrated the presence of anti-CCP antibodies in infectious diseases, particularly TB. These findings may represent a disturbance to clinicians attending patients in countries such as Brazil, where there is high frequency of these diseases, mainly because osteoarticular manifestations are presented during the course of many of them. Bearing in mind this concern, we performed a systematic review on this subject, which revealed studies demonstrating a positivity of anti-CCP antibodies in TB ranging from 0 to $37 \%$ [17]. In the present study, there was low positivity of ACPA in TB resulting in high specificity of the test for RA. The discrepancy of our results in comparison with those of previous studies may be attributed to methodological causes, particularly due to the use of different kits, or the use of "in-house" ELISA. It should be noted that one cannot exclude the hypothesis that the positivity of ACPAs in TB observed in some studies could be related to the specificity of these antibodies to non-citrullinated epitopes of the substrate, and thus, the choice of kit to perform this test assumes a relevant importance, particularly in countries where there is high prevalence of TB. Alternatively, the diversity of the studied populations may also have contributed to this difference or one should even consider the possibility of transitory positivity of these antibodies in $\mathrm{TB}$, considering that no study has repeated its dosage.

In conclusion, the positivity of ACPA antibodies in TB was observed to be low. In addition, the good diagnostic performance of ACPA for the detection of RA was confirmed.

Acknowledgments M.S. receives a scholarship from the Conselho Nacional de Desenvolvimento Científico e Tecnológico. We are indebted to the pneumologists of Hospital Otávio Mangabeira, where the TB patients came from.

Disclosures None.

\section{References}

1. Symmons DP, Barrett EM, Bankhead CR, Scott DG, Silman AJ (1994) The incidence of rheumatoid arthritis in the United Kingdom: results from the Norfolk Arthritis Register. Br J Rheumatol 33(8):735-739

2. Marques Neto J, Gonçalves E, Langen L, Cunha M, Radominski S, Oliveira $S$ et al (1993) Estudo multicêntrico da prevalência da artrite reumatóide do adulto em amostras da população brasileira. Rev Bras Reumatol 33:169-173

3. Senna ER, De Barros AL, Silva EO, Costa IF, Pereira LV, Ciconelli RM et al (2004) Prevalence of rheumatic diseases in Brazil: a study using the COPCORD approach. J Rheumatol 31(3):594-597

4. Aletaha D, Neogi T, Silman AJ, Funovits J, Felson DT, Bingham CO III et al (2010) Rheumatoid arthritis classification criteria: an American College of Rheumatology/European League Against Rheumatism collaborative initiative. Arthritis Rheum 62(9):2569-2581

5. Arnett FC, Edworthy SM, Bloch DA, McShane DJ, Fries JF, Cooper NS et al (1988) The American Rheumatism Association 1987 revised criteria for the classification of rheumatoid arthritis. Arthritis Rheum 31(3):315-324

6. Mota LM, Laurindo IM, Santos Neto LL (2010) Early rheumatoid arthritis: concepts. Rev Assoc Med Bras 56(2):227-229, Mar

7. Goldbach-Mansky R, Lee J, McCoy A, Hoxworth J, Yarboro C, Smolen JS et al (2000) Rheumatoid arthritis associated autoantibodies in patients with synovitis of recent onset. Arthritis Res 2 (3):236-243

8. Schellekens GA, Visser H, de Jong BA, van den Hoogen FH, Hazes JM, Breedveld FC et al (2000) The diagnostic properties of rheumatoid arthritis antibodies recognizing a cyclic citrullinated peptide. Arthritis Rheum 43(1):155-163

9. Whiting PF, Smidt N, Sterne JA, Harbord R, Burton A, Burke M et al (2010) Systematic review: accuracy of anti-citrullinated peptide antibodies for diagnosing rheumatoid arthritis. Ann Intern Med 152(7):456-464, Apr 6

10. Elkayam O, Segal R, Lidgi M, Caspi D (2006) Positive anti-cyclic citrullinated proteins and rheumatoid factor during active lung tuberculosis. Ann Rheum Dis 65(8):1110-1112

11. Elkayam O, Segal R, Bendayan D, Van UR, Onnekink C, Pruijn GJ (2010) The anti-cyclic citrullinated peptide response in tuberculosis patients is not citrulline-dependent and sensitive to treatment. Arthritis Res Ther 12(1):R12

12. Kakumanu P, Yamagata H, Sobel ES, Reeves WH, Chan EK, Satoh M (2008) Patients with pulmonary tuberculosis are frequently positive for anti-cyclic citrullinated peptide antibodies, but their sera also react with unmodified arginine-containing peptide. Arthritis Rheum 58(6):1576-1581

13. Mori S, Naito H, Ohtani S, Yamanaka T, Sugimoto M (2009) Diagnostic utility of anti-cyclic citrullinated peptide antibodies for rheumatoid arthritis in patients with active lung tuberculosis. Clin Rheumatol 28(3):277-283

14. Silva A, Matos A, Lima A, Lima E, Gaspar A, Braga J et al (2006) Valor diagnóstico do anticorpo antipeptídeo citrulinado cíclico na artrite reumatóide. Rev Bras Reumatol 46:174-180

15. Nienhuis RL, Mandema E (1964) A new serum factor in patients with rheumatoid arthritis; the antiperinuclear factor. Ann Rheum Dis 23:302-305

16. Santiago M, Baron M, Miyachi K, Fritzler MJ, Bu-Hakima M, Leclercq $S$ et al (2008) A comparison of the frequency of antibodies to cyclic citrullinated peptides using a third generation anti$\mathrm{CCP}$ assay $(\mathrm{CCP} 3)$ in systemic sclerosis, primary biliary cirrhosis and rheumatoid arthritis. Clin Rheumatol 27(1):77-83

17. Lima I, Santiago M (2010) Antibodies against cyclic citrullinated peptides in infectious diseases - a systematic review. Clin Rheumatol 29(12):1345-1351 